УДК 636.8.09:616.37

(C) 2018

Кравченко С. О., кандидат ветеринарних наук,

Боброва В. В., аспірант

(науковий керівник - кандидат ветеринарних наук С. О. Кравченко)

Полтавська державна аграрна академія

\title{
УЛЬТРАСОНОГРАФІЧНІ ЗМІНИ ЗА ГОСТРИХ І ХРОНІЧНИХ ЗАПАЛЕНЬ ПІДШЛУНКОВОЇ ЗАЛОЗИ У СВІЙСЬКИХ КОТІВ
}

\section{Рецензент - кандидат ветеринарних наук Н. І. Дмитренко}

Діагностика захворювання підшлункової залози запального характеру за відсутності специфічних тестів: SPLI (специфічна панкреатична ліпаза у котів) та TLI (трипсиноподібна імунореактивність), які на сьогодні є золотим стандартом під час діагностики панкреатитів у котів свійських, але недоступні поки щзо у нашій країні для клініџистів, є досить складною за відсутності специифічної клінічної картини, щуо пов'язано з особливістю перебігу даного захворювання у даного виду тварин. Ультразвукові сканери $з$ високочутливими датчиками на сьогодні є відносно доступними у повсякденній практииі ветеринарного лікаря і даний візуальний метод діагностики дає змогу оцінити наявність чи відсутність структурних змін у підшлунковій залозі котів свійських з неспециифічною клінічною картиною захворювання. У статті проведено аналіз можливостей ультразвукового методу діагностики під час дослідження даного органу у даного виду тварин клінічно здорових $і$ хворих та проведена кореляція виявлених змін із клінічними симптомами захворювання.

Ключові слова: ультразвукове дослідження, підшлункова залоза, коти свійські, діагностика.

Постановка проблеми. Запалення підшлункової залози у котів свійських у більшості випадків має хронічний перебіг і у загальній клінічній практиці залишається невиявленим за відсутності специфічної симптоматики. Найбільш поширеними ознаками панкреатиту у котів $\epsilon$ анорексія, летаргія, зниження температури тіла, зневоднення, може виявлятися жовтяниця, легка анемія. Класичні симптоми - блювота та біль у животі, - у котів реєструються лише у половині випадків [1].

Ехографію підшлункової залози здійснюють для підтвердження іiі патології. Даний метод становить широкий інтерес і для повсякденної ветеринарної практики, бо є на сьогодні вже більш доступним 3 появою ультразвукових апаратів експертного класу. Це не інвазійний метод, який дає змогу в екстренному порядку, об’єктивно та без побічного впливу на обстежуваний організм отримати відомості про стан підшлункової залози та інших внутрішніх органів у кожній конкре- тній ситуації. Крім того, за допомогою ехографії з'явилася можливість проводити ефективно не тільки діагностичні, але і малоінвазивні втручання біопсію чи дренаж патологічних утворень.

У гуманній медицині метод ультразвукового дослідження широко застосовується для діагностики та моніторінгу пацієнтів із патологіями підшлункової залози. У ветеринарній медицині можливості даного методу, питання ультразвукової семіотики патологічних змін у підшлункової залози висвітлені епізодично та потребують подальших досліджень.

Аналіз основних досліджень і публікацій, у яких започатковано розв'язання проблеми. Аналізуючи дані літературних джерел, слід зазначити, що згідно з проведеними дослідженнями, у свійських котів метод ультрасонографії підшлункової залози має досить високу варіабельність інформативності - 75-84 \% (Ларсон) за одними джерелами та 11-67 \% згідно з результатами інших досліджень [2]. Така розбіжність пов'язана 3 технічними можливостями апаратури, що застосовується, досвідом лікаря ультразвукової діагностики та ступенем ураження органу. До патологій підшлункової залози, які найчастіше реєструють у дрібних домашніх тварин, належать панкреатит гострий та хронічний з супутніми ускладненнями, вузлову гіперплазію та новоутворення [4].

Мета дослідження: проаналізувати інформативність методу ультрасонографії підшлункової залози за іï патологічного стану у свійських котів.

Матеріали і методи досліджень. Дослідження проводили на базі клініки ветеринарної медицини «VetExpert» м. Полтава. Об'єктом дослідження були свійські коти різних вікових груп, порід та статей. На сьогодні обстежено 132 тварини, які були направлені на УЗ обстеження 3 патологіями, не пов'язаними 3 підшлунковою залозою, та 3 підозрою на патологію підшлункової залози. 
ВЕТЕРИНАРНА МЕДИЦИНА

Виявлені ехозміни підшлункової залози у свійських котів за патології

\begin{tabular}{|c|c|c|c|c|}
\hline$\Pi / \Pi$ & $\begin{array}{c}\text { Вік тва- } \\
\text { рини }\end{array}$ & Діагноз & $\begin{array}{c}\text { Клінічні } \\
\text { прояви }\end{array}$ & $\begin{array}{c}\text { Ехозміни у } \\
\text { підшлунковій залозі }\end{array}$ \\
\hline 1 & 16 років & XXH & \begin{tabular}{|c|} 
Анорексія, \\
хронічна блювота \\
\end{tabular} & Зниження ехогенності \\
\hline 2 & 9 років & Тріадіт & $\begin{array}{c}\text { Хронічна } \\
\text { блювота, діарея }\end{array}$ & $\begin{array}{c}\text { Дифузне } \\
\text { підвищення ехогенності }\end{array}$ \\
\hline 3 & 2 роки & $\begin{array}{c}\text { Сторонне тіло в } \\
\text { тонкому кишківнику }\end{array}$ & Гостра блювота & Зниження ехогенності \\
\hline 4 & 6 років & $\begin{array}{l}\text { Хронічний панкреатит } \\
\text { у диференційному } \\
\text { діагнозі }\end{array}$ & Анорексія & Дифузне підвищення ехогенності \\
\hline 5 & 2,5 роки & Панкреатит & Анорексія & $\begin{array}{c}\text { Дифузне зниження ехогенності, розширення } \\
\text { протоку до } 2,3 \text { мм }\end{array}$ \\
\hline 6 & 19 років & $\begin{array}{c}\text { Пухлина молочної } \\
\text { залози }\end{array}$ & $\begin{array}{c}\text { Анорексія, хроні- } \\
\text { чна блювота }\end{array}$ & $\begin{array}{c}\text { Гіпоехогенні вузли в товщі паренхіми під- } \\
\text { шлункової залози }\end{array}$ \\
\hline 7 & 6 років & Тріадіт & $\begin{array}{c}\text { Анорексія, } \\
\text { хронічна блювота } \\
\end{array}$ & $\begin{array}{c}\text { 3ниження ехогенності, збільшення розмірів } \\
\text { підшлункової залози до 11,9 мм }\end{array}$ \\
\hline 8 & 10 років & Панкреатит & Анорексія, апатія & $\begin{array}{c}\text { Зниження ехогенності, збільшення розмірів } \\
\text { підшлункової залози до 12,1 мм, нерівність } \\
\text { контурів }\end{array}$ \\
\hline 9 & років & ВІД & Анорексія & Змішана ехогенність паренхіми \\
\hline 10 & 1 рік & ВПम & $\begin{array}{c}\text { Перитонеальний } \\
\text { випіт }\end{array}$ & $\begin{array}{c}\text { Дифузне зниження ехогенності, контур нері- } \\
\text { вний, значне збільшення розмірів залози }\end{array}$ \\
\hline 11 & 3 роки & Панкреатит, тріадіт & $\begin{array}{l}\text { Анорексія, блю- } \\
\text { вота }\end{array}$ & $\begin{array}{c}\text { Дифузне зниження ехогенності, контур нері- } \\
\text { вний, значне збільшення розмірів, розши- } \\
\text { рення протоку до 2,5 мм }\end{array}$ \\
\hline 12 & 16 років & Лімфома нирки & Анорексія, апатія & Дифузне підвищення ехогенності \\
\hline 13 & міс. & $\begin{array}{c}\text { Стороннє тіло у тонко- } \\
\text { му кишківнику }\end{array}$ & $\begin{array}{c}\text { Анорексія, блю- } \\
\text { вота }\end{array}$ & $\begin{array}{c}\text { Дифузне зниження ехогенності, розширення } \\
\text { протоку до } 2,4 \text { мм }\end{array}$ \\
\hline 14 & 3,5 років & Панкреатит, тріадіт & Хронічна блювота & Змішана ехогенність паренхіми \\
\hline 15 & 6 мiс. & $\begin{array}{l}\text { Стороннє тіло у тонко- } \\
\text { му кишківнику }\end{array}$ & $\begin{array}{l}\text { Анорексія, } \\
\text { блювота }\end{array}$ & $\begin{array}{l}\text { Дифузне зниження ехогенності, розширення } \\
\text { протоки до 2,4 мм, підвищення ехогенності } \\
\text { жирової тканини біля підшлункової залози }\end{array}$ \\
\hline 16 & 1,1 рік & ВПК & \begin{tabular}{|c|}
$\begin{array}{c}\text { Перитонеальний } \\
\text { випіт }\end{array}$ \\
\end{tabular} & Дифузне зниження ехогенності \\
\hline 17 & 11 років & XXH & $\begin{array}{c}\text { Анорексія, } \\
\text { хронічна блювота }\end{array}$ & Дифузне зниження ехогенності \\
\hline 18 & 2,5 років & $\begin{array}{c}\text { Хронічний панкреатит } \\
\text { в диференційному діаг- } \\
\text { нозі }\end{array}$ & Хронічна блювота & $\begin{array}{c}\text { Підвищення ехогенності паренхіми, розши- } \\
\text { рення протоку до 2,6 мм }\end{array}$ \\
\hline 19 & 6 років & Цукровиї & $\begin{array}{l}\text { Полідипсія/ } \\
\text { поліфагія }\end{array}$ & $\begin{array}{c}\text { Дифузне зниження ехогенності, збільшення } \\
\text { розмір, розширення протоку до 2,1 мм }\end{array}$ \\
\hline 20 & 7 років & Лімфома кишківника & Діарея & $\begin{array}{l}\text { Збільшення розмірів, кістозні утворення в } \\
\text { товщі паренхіми }\end{array}$ \\
\hline 21 & 4 роки & $\begin{array}{l}\text { Без клінічних ознак } \\
\text { захворювання }\end{array}$ & $\begin{array}{c}\text { Без клінічних } \\
\text { ознак захворю- } \\
\text { вання }\end{array}$ & $\begin{array}{l}\text { Дифузне зниження ехогенності, збільшення } \\
\text { розмір, розширення протоку до 4,0 мм }\end{array}$ \\
\hline 22 & 14 років & $\begin{array}{l}\text { Гіпертиреоз, ДКМП, } \\
\text { тріадіт }\end{array}$ & Зниження апетиту & $\begin{array}{c}\text { Дифузне зниження ехогенності, відносне } \\
\text { збільшення розмірів, поява кальцифікатів та } \\
\text { гіпоехогенних вузлів у паренхімі }\end{array}$ \\
\hline
\end{tabular}

Примітка: ХХН - хронічні хвороби нирок, ВІД - вірусний імунодефіцит, ВПК - вірусний перитоніт котів. 


\section{ВЕТЕРИНАРНА МЕДИЦИНА}

Хворих тварин оглядали клінічно, проводили збір анамнестичних даних. Паралельно досліджували окремі біохімічні та фізичні показники крові, сечі.

Ультразвукові дослідження проводили ультразвуковим сканером «IMEGIC Elite» (серія «Sigma 5000») «KONTRONMEDICAL», лінійним датчиком 3 частотою 7,5-12 МГц у В-режимі. Перед проведенням ультразвукового дослідження органів черевної порожнини в неургентних ситуаціях та за відсутності блювоти рекомендували 12-годинну голодну дієту та пероральне задавання сорбенту «Ентеросгель» у кількості 5 г на дорослу тварину та попередне заповнення шлунка водою (випоювання безпосередньо перед дослідженням у об'ємі 10-20 мл).

Шерсть перед проведенням дослідження голили, на шкіру наносили спеціальний гель. У котів краще візуалізується тіло та ліва доля підшлункової залози [3, 4], тому акцент робили на дослідженні саме цієї частини органу, паралельно обстежували гепато-біліарну систему та органи шлунково-кишкового тракту, а саме шлунок і дванадцятипалу кишку, адже у $80 \%$ котів проток підшлункової залози та жовчні протоки зливаються у загальну протоку, яка впадає у дванадцятипалу кишку.

Такий тісний анатомічний зв'язок печінки, підшлункової та дванадцятипалої кишки у даного виду тварин передбачає одночасне запалення усіх трьох органів $[1,2]$.

Тварин досліджували в дорсо-ветральному положенні за вентрального доступу. Під час дослідження підшлункової залози оцінювали контури (рівні чи нерівні), ехогенність (нормальна, знижена чи підвищена), поширеність ехогенності (локально чи дифузно), вимірювали ширину залози та панкреатичного протоку, наявність перитонеального випоту, проводили оцінку стану оточуючих тканин, дванадцятипалої кишки та ілеусу (товщина стінок та можливість диференціації шарів, перистальтика), оцінку прохідності жовчних шляхів (форма, розташування жовчного міхура, оцінка контурів, об'єму та однорідності жовчі, діаметр загального жовчного протоку). Згідно з даними літератури, у клінічно здорових тварин відмічається ізоехогенність паренхіми залози 3 печінковою паренхімою та жировою тканиною брижі, діаметр протоки - від 0,5 до 2,0 мм. Діаметр лівої долі в середньому становить від 3,0 до 10,0 мм [4].

Результати досліджень. Лише 1,6 \% котів потребували попередньої анестезії у зв'язку з підвищеною агресією, частіше всього це стосувалося здорових тварин, 98,4\% котів досить добре реагували на обстеження. У 75 \% тварин досить добре візуалізували ліву долю підшлункової залози 3 центральним протоком, який ідентифікували за допомогою енергетичного доплера, лише у $25 \%$ - тіло та праву долю.

Результати досліджень інтерпретували 3 урахуванням даних анамнезу, клінічних та лабораторних досліджень. Найкраща візуалізація цього органу реєструвалася у тварин 3 перитонеальним випотом та у тварин зі зниженою чи нормальною вагою.

Зміни в ехокартині підшлункової залози були зареєстровані у 22 випадках (див. табл.).

Таким чином, для діагностики запальних процесів у підшлунковій залозі у котів свійських брали до уваги зниження (рис. 1) чи підвищення ехогенності органу (рис. 2), підвищення ехогенності оточуючих тканин (рис. 3), збільшення розмірів залози без зміни чи зі зміною діаметра центрального протока (рис. 4), атонію дванадцятипалої кишки, порожнисті утворення у підшлунковій залозі (наприклад, псевдокісти) (рис. 5, 6), що характерно для розвитку запальних процесів у цьому органі.

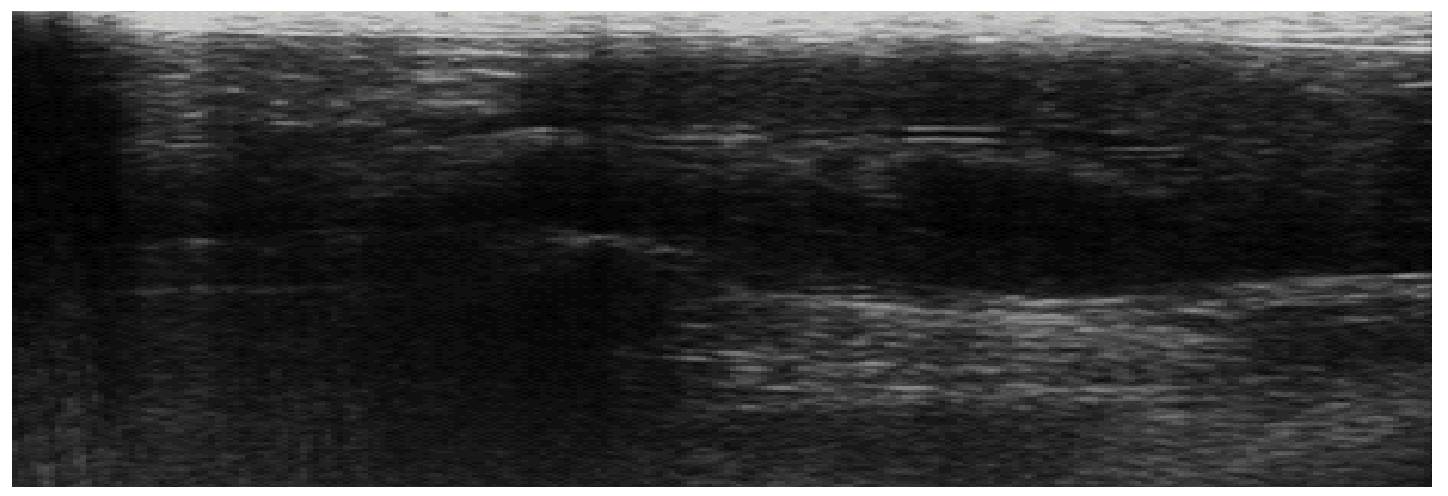

Рис. 1. Дифузне зниження ехогенності паренхіми підилункової залози, збільшення розмірів 


\section{ВЕТЕРИНАРНА МЕДИЦИНА}

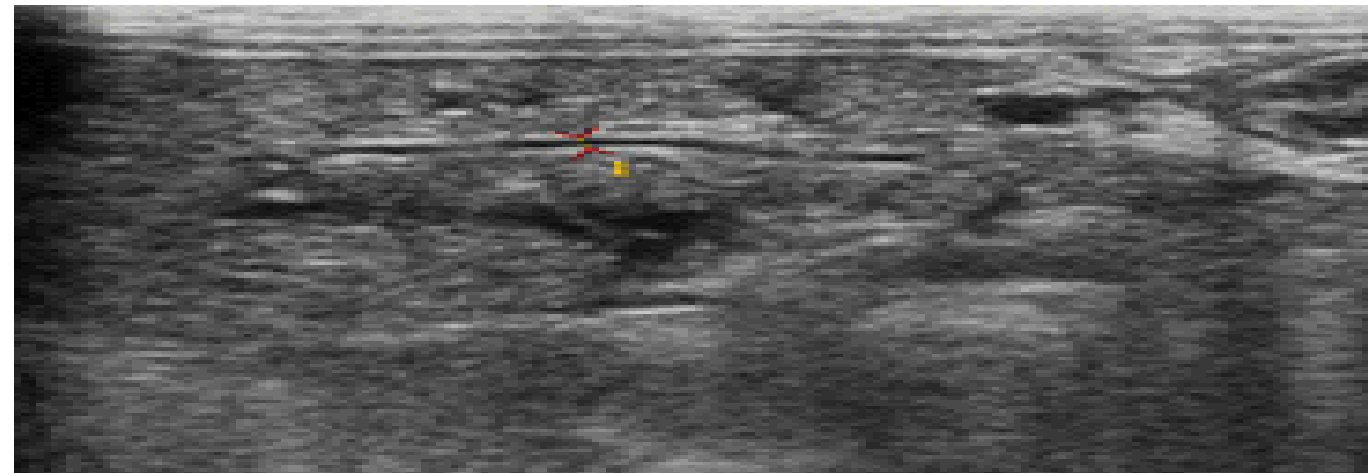

Рис. 2. Дифузне підвищення ехогенності паренхіми підилункової залози

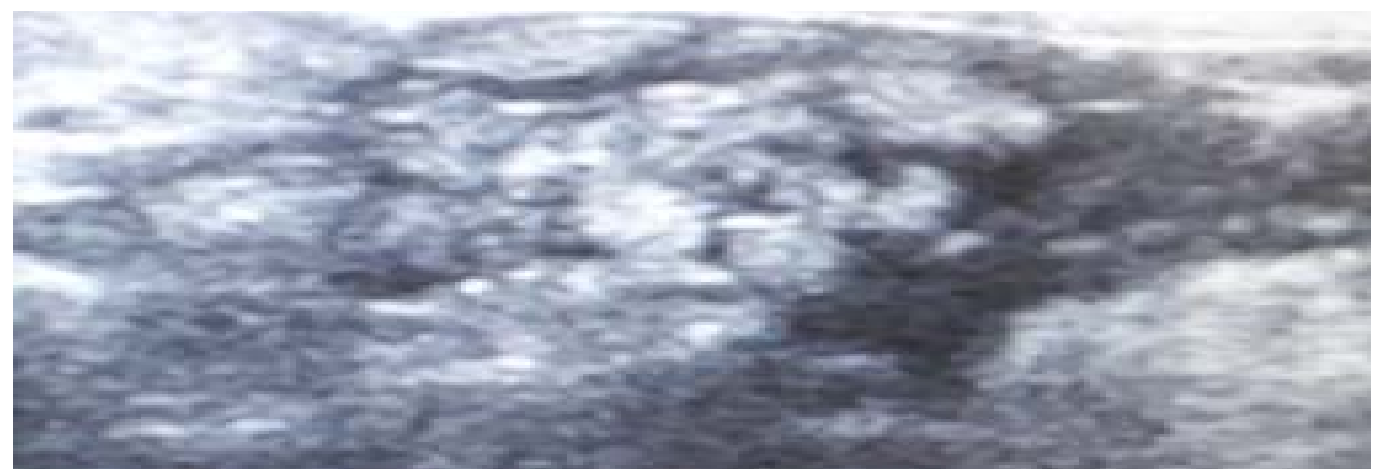

Рис. 3. Підвищення ехогенності оточуючих тканин, локальний випіт

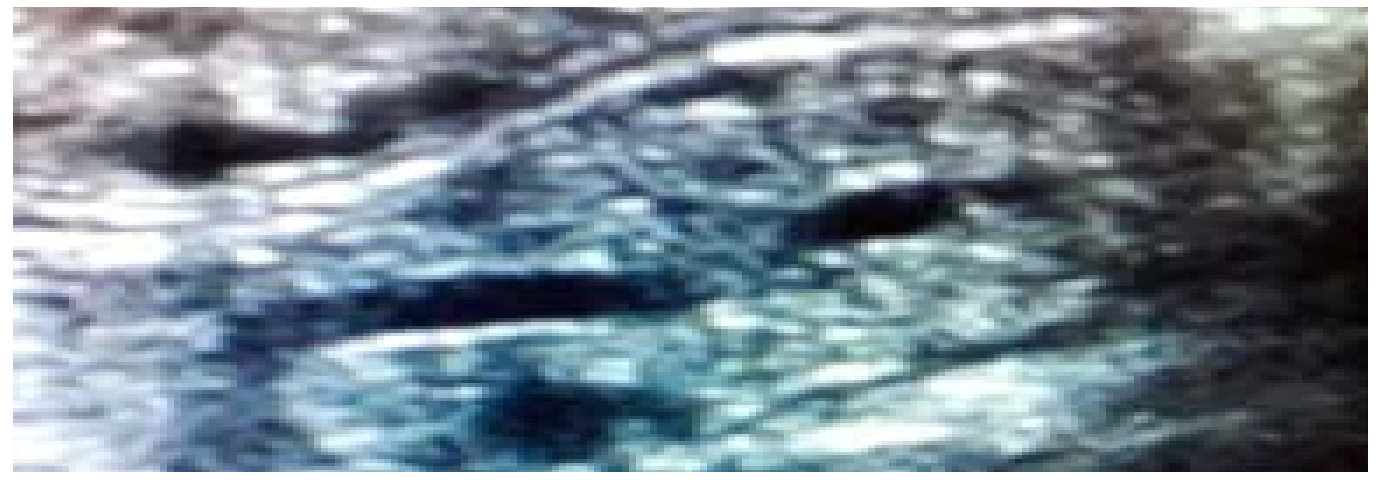

Рис. 4. Розширення центрального панкреатичного протоку

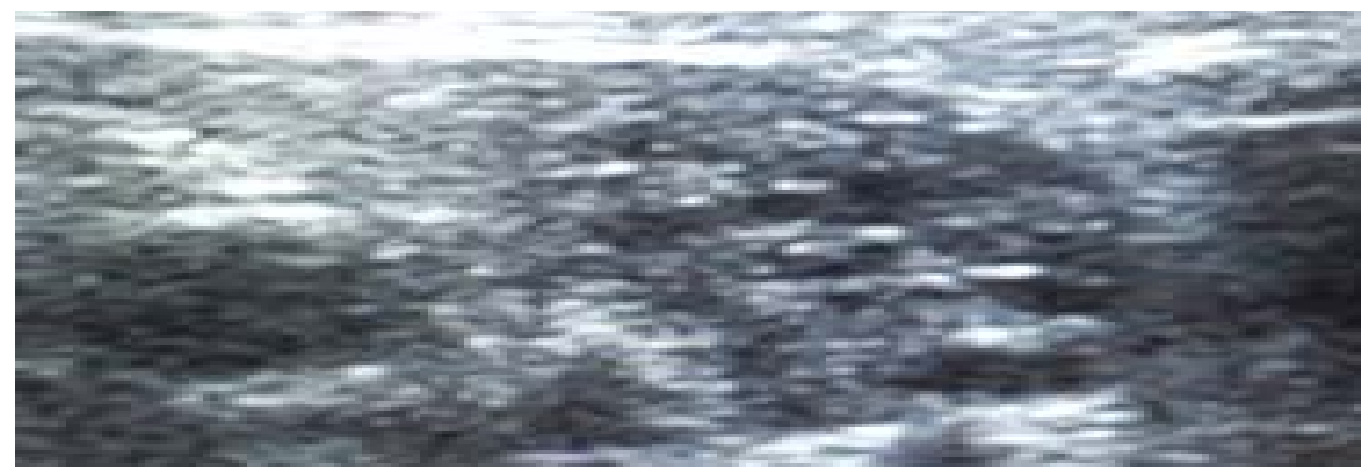

Рис. 5. Анехогенні порожнисті утворення в паренхімі підилункової залози 


\section{ВЕТЕРИНАРНА МЕДИЦИНА}

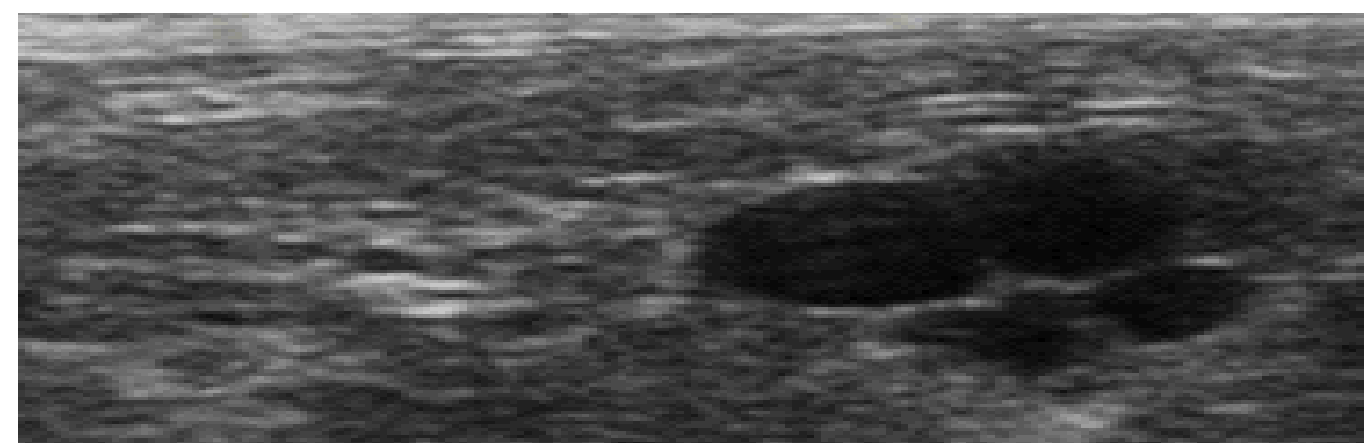

Рис. 6. Анехогенні порожнисті утворення в тканинах, що оточують підилункову залозу

Висновок. Таким чином, ультразвукове дослідження підшлункової залози у котів свійських $€$ перспективним методом діагностики патологічних станів цього органу, так як підшлункова залоза у свійських котів досить добре візуалізується за допомогою ультразвуку, навіть без по-

\section{БІБЛІОГРАФІЯ}

1. Каттен И. Сочетание панкреатита с холангиогепатитом и воспалительным заболеванием кишечника (триадит) у кошек / И. Каттен // Фокус. - 2013. - Том 23. - №2. - С. 4-10.

2. Ксенуліс П., Штайнер Й. Панкреатит у кошек / П. Ксенуліс, Й. Штайнер // Фокус. - 2009. - Том 19. - №2 . - С. 11-20. передньої голодної дієти. Отримані дані мають діагностичну цінність для виявлення патологічних станів підшлункової залози у цього виду тварин і потребують подальших досліджень у цьому напрямі.

3. Маннион П. Ультразвуковая диагностика заболеваний мелких домашних животных / П. Маннион. - М. : Аквариум, 2008.

4. Пенник Д. Атлас по ультразвуковой диагностике. Исследования у собак и кошек / Д. Пенник, М.-А. Д’Анжу. - М. : Аквариум-Принт, 2015. 